\title{
Identification and classification of facilities managers functions: A proposal validated by Latin American experts
}

\author{
Manuel Madroñal-Ortiz****, Diego Cuartas-Ramirez***, Carlos Angel Benavides-Velasco** \\ and Marisol Osorio*** \\ * Bioengineering Research Group, School of Engineering, Pontificia Bolivariana University, Medellin, 050031, Colombia. \\ ** Department of Economics and Business Administration, School of Industrial Engineering, Malaga University, Malaga, 29071, Spain. \\ *** Technology and Innovation Management Research Group, School of Engineering, Pontificia Bolivariana University, Medellin, 050031, \\ Colombia. \\ *Corresponding Author: manuel.madronal@upb.edu.co
}

$\begin{array}{ll}\text { Submitted } & : 16 / 11 / 2020 \\ \text { Revised } & : 29 / 09 / 2021 \\ \text { Accepted } & : 11 / 10 / 2021\end{array}$

\begin{abstract}
The functions performed by facility management practitioners and their classification have evolved over the last decades. The practice of Facility Management integrates many professions; however, certain authors have pointed out that heterogeneous views are generated by those responsible for the facilities, and this has caused confusion about the understanding of the discipline in recent years. In addition, different attitudes about the discipline have been presented depending on the vision of the British or American schools of FM, which face the objectives and tasks throughout these years in different ways. This causes diffuse areas that prevent the identification of the entire spectrum of functions related to support activities in a facility management system. The objective of this research was to identify and classify the functions performed until the present time by facility managers in the literature to establish the scope of a facility management system. In this work, the authors carried out a review of the literature and an analysis of the different documents that gave rise to a proposal of the different functions performed and their classification into main areas. Later, a validation of the proposal was requested through an expert consultation in facility management in Latin America, which reached 94\% approval. The validated proposal is composed of at least 37 functions performed by facility management professionals, and these functions can be classified into six main areas: Asset and Maintenance Management; Real Estate and Property Management; Energy and Sustainability Management; Corporate Project Management; Workplace Management; and Facilities Services Management.
\end{abstract}

Keywords: Areas; Expert consultation; Facility management; Functions; Support activities.

\section{INTRODUCTION}

The functions to be performed by facilities managers (FMer), related to organizational support activities, are generally grouped into different areas of knowledge related to buildings, people, technology, and processes. Definitions of FM have evolved as shown by various authors (Tay \& Ooi, 2001; Nor \& Azman, 2014) in recent decades, and another factor is the perspective of professional FM associations. However, the authors of this work 
understand that "the FM integrates multiple disciplines in order to influence the efficiency and productivity of societies, organizations, and communities, as well as the way in which individuals interact with the built environment" (UNE, 2018). Likewise, from the point of view of Maliene, Baldry and Alexander (2005), in the evolution of the profession, and with the growth of new technologies, the FM has expanded the portfolio of support services from the 'traditional'. Therefore, today, the FM profession includes many activities and different processes that are difficult to define, which may be one of the reasons why there is no common identification and classification of these types of functions.

In the variety of definitions of FM, it can be identified as two different schools of FM that differ in their attitude towards the key objectives and tasks of this type of activity. The American FM is focused on organizational effectiveness, and the British FM is focused on cost efficiency (Nor \& Azman, 2014). These visions were caused because the original meaning of FM when arriving in the United Kingdom (UK) was confused the design of the workplace with the provision and outsourcing of services for the building (Price, 2002). Even Thomson (1998) cited by Nor \& Azman (2014) claims that the term 'facilities' was adopted in the UK for both the workplace designer and operational building managers. This shows that there may be a confusion when it comes to understanding the scope of functions to be performed by the FMer depending on which FM school is considered.

As one of the most representative FM professional associations in Spanish, IFMA-Spain (2019) indicates that the basic functions included in FM are as follows: the development of corporate strategies regarding real estate resources, space optimization policies, coordination of construction projects, renovation and relocation, recruitment of all products and services related to the proper functioning of the facilities, conservation and maintenance of facilities, and building services engineering. Similarly, according to the definition of the International Facilities Management Association (IFMA), FM mainly includes nine functions (Hu, Zhang, Yu, Tian \& Xiang, 2016): longterm facility management plan; short-term facility management plan; facility financing analysis and financial management; real estate disposal and management; internal space planning; space standards and space management; construction planning and design of new or rebuilt projects; construction of new or rebuilt projects; daily operation and maintenance of facilities, communication, security, and other support services.

However, the authors of this work understand that the spectrum of functions performed by FMer is much broader than what was previously exposed. In addition, the mission of the different functions of the FMer organized in different areas of the FM helps achieve employees' wellbeing and support the organizational objectives in a way that provides the highest return on resources (Duque, 2017). The authors of this work argue that the evolution of generational definitions of FM, highlighted by various authors (Tay \& Ooi, 2001; Nor \& Azman, 2014), is related to the evolution of the functions performed by FMer over time by Myeda (2014), exposed in Figure 1. Several decades ago, organizations have evolved from solving operational problems to a more strategic approach that will increase profitability and support core activities to ensure successful results (APPA, 2002). 


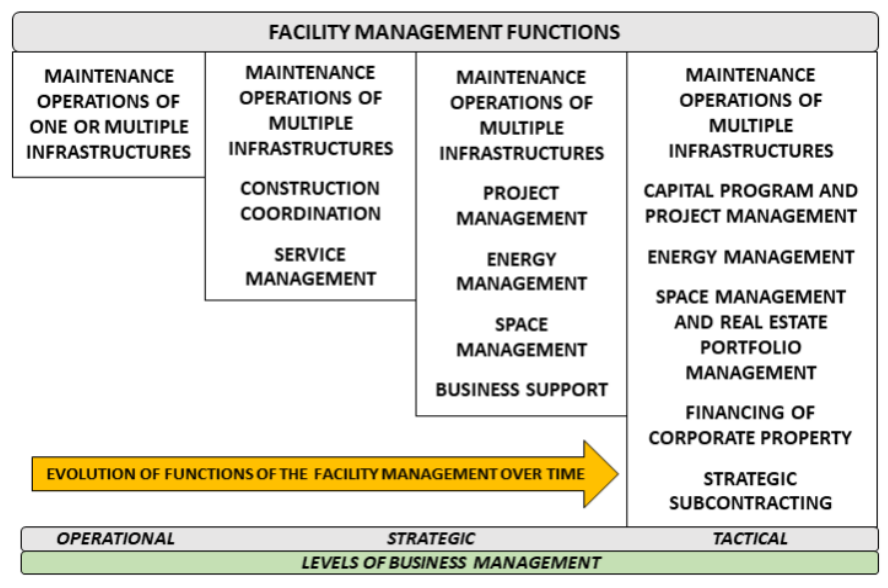

Figure 1. Evolution of the functions performed by the FMer (Adapted from Myeda, 2013).

Since the FM encompasses the operational, tactical, and strategic levels of an organization's support activities, the domain of the FM is very broad. Its influence on an enterprise encompasses many functions and responsibilities that are grouped into different areas. The functions of the FMer are usually grouped in different areas depending on each organization or industrial sector, including the grouping in different areas that aims to sectorize and strengthen all processes to encourage coordination of employees in their workplaces, in a pleasant and supportive performance environment that provides optimal performance (Kampf, 2008). This type of grouping of functions is associated in the same way that the BIFM classifies the roles of the FM in the following six groups that, in turn, are linked to any of the three levels of business management mentioned (IFMA-Spain, 2014): understand the organization of the company; manage people; manage real estate; manage services; manage the work environment; manage resources.

On the one hand, a way to organize the functions of the FM, as presented by Isa, Kamaruzzaman \& Mohamed (2019) in a conceptual framework of the functions of the FM in the study of value management, is the classification in five main areas that are associated with the distribution of the four representative areas according to IFMA: people (customer satisfaction), processes (operation \& maintenance), space (space management, sustainability, and energy efficiency), and technology (space management and operation \& maintenance). On the other hand, FM consulting firms such as FM-House (2015) group function in five different areas: real estate management, space and project management, service management, environmental management, and strategic management and support.

In any case, only the development of standards to create a European concept of FM by the European Committee for Standardization (CEN) exposes the functions performed by FMer and their classification (UNE, 2012). However, with a standard already repealed and the disparity in the publications of the authors of the literature, this causes the existence of diffuse areas in the understanding of this discipline that prevent the identification of the entire spectrum of functions related to support activities to establish a Facility Management System (FMS). The current ISO 41001 (ISO, 2018) standard for the establishment of an FMS indicates that the organization "must establish FM objectives in the relevant functions, subfunctions, and levels" and "must demonstrate that it has integrated its FM functions to ensure the effective and efficient provision of FM services." However, the ISO 41001 standard or other complementary standards in force on FM do not indicate what are the functions to be performed by FM practitioners.

As stated above, the agreement between FM practitioners in appointing their functions and the way to group FM activities is confusing, due to the endless visions of each researcher, practitioner, or FM professional organization. Therefore, the objective of this work was to identify adequately a number of FMer functions and classify them into 
several main areas of FM that comprise most of the organizational support activities. This work was carried out through a review of the literature and identification and classification of the functions of the FMer, and later, a consultation was carried out with Latin American experts who mainly supported the proposal of the authors of this work.

\section{METHODOLOGY}

\section{Literature Review}

Initially, a literature review was carried out between 1990 and 2019 using a metasearch system and the exploration of multidisciplinary academic databases (Scopus, Web of Science, SciELO, Google Scholar, and ResearchGate), with the use of the following keywords and their Boolean combinations in Spanish and English: FM discipline (Facility Management or Facilities Management), functions (funciones), areas (áreas), responsibility (responsabilidad), and competences (competencias). Secondly, it was initially analyzed that the documents selected in the first instance linked the functions of the FMer in different areas or categories for this specific case at the different levels of business management (strategic, tactical, and operational).

\section{Benchmarking}

The documents identified were ordered by publication date, and the information was ordered according to the areas of the FM or considering the functions of the FMer. One of the latest publications (Castro \& Plaza, 2019) was taken as a guide, which expresses and presents in detail a list of functions of the FMer associated with various areas of the FM, covering a wide spectrum of support activities of any organization. For the composition of a proposal of the FMer areas, the authors arranged the information found in a matrix based on the guide document (Castro \& Plaza, 2019). In the same way, for the composition of a proposal of the FMer functions found in the documents, these functions were accommodated in the elements of another matrix based on the mentioned guide document.

\section{Expert Consultation}

The proposals of FMer's functions and their classification in several main areas of the discipline were sent by e-mail to a number of FM experts from Latin America for validation. An expert consultation is a method that allows asking a group of competent people in a subject to validate a proposal based on knowledge, research, experiences, bibliographic studies, etc. (Robles-Garrote \& Rojas, 2015). The purpose of validation by experts is to express knowledge to the community and systematically collect responses for subsequent qualitative analysis (García Valdés \& Suarez Marín, 2013). In order to gather a group of experts, it was necessary to configure a questionnaire to quantify the competences and experience on the subject of study that would guarantee the result of the validation. In this case, a version of the expert competence calculation method " $\mathrm{K}$ " was developed for the approval of experts (Cabero \& Barroso, 2013) that rated their experience and competencies of FM. The questionnaire sent to the experts included a brief description of the project, the objectives pursued, the expected number of rounds, and the estimated time of the process (Gordon, 1994), as well as the time for acceptance and completion. In this case, it was established that the number of experts for content validation was less than 50 (Witkin \& Altschuld, 1995) and that it was greater than 15 subjects (Gordon, 1994; García \& Fernández, 2008). In the second part of the questionnaire on the functions and areas of FM, a documentary review of the summary of the work carried out in the literature review was requested, and then the choice of one of the three options on the distribution of the main areas of FM in any organization. Subsequently, in each of the options, the expert could propose various functions and areas of the FM, according to his knowledge on the profession. 


\section{Conformity of the Consultation}

Once the responses from the experts were received, a qualitative analysis of the rating of the responses on the experts' competencies and experience in FM was performed by means of a statistical analysis of central tendency. In addition, the authors of this work carried out another qualitative analysis of the responses obtained in the single round of consultation on the proposals for the functions of the FMer and their classification into main areas, through descriptive statistics that supported qualitative information from the comments issued by the respondents. To validate the results obtained, in the FM functions, they had to exceed at least $50 \%$ of the acceptance of the experts consulted (García Valdés \& Suarez Marín, 2013). The consensus method of the aforementioned proposals used is essentially related to obtaining descriptive statistical estimates from qualitative approximations (Jones \& Hunter, 1995).

\section{RESULTS AND DISCUSSION}

The results of the literature review between 1990 and 2019 were 17 documents that were published in books, research papers, doctoral theses, regulations, and informative documents. The results obtained in this review have been limited due to the keywords mentioned and the exclusion of the documents that did not specify functions of the FMer or their classification in areas of the FM. For this reason, it is possible to miss documents by notable authors that exposed the role of the FM in the organization, but not the functions to be performed by the FMer or their classification.

\section{Analysis of the Literature Review}

The selected documents were ordered in Table 1 by date of publication to observe the evolution proposed by the different authors, which varied between 4 and 10 areas. In the opinion of the exposed by Ee (2015), the authors of this work have considered that a number greater than 7 main areas of FM is not recommended for the effective management of FM. Therefore, the authors of this work decided to propose as an adequate number the 6 areas exposed by Martínez (Castro \& Plaza, 2019), and the areas appearing in the documents were accommodated by similarity in Table 1 according to the following areas of the guidance document: Asset \& Maintenance Management, Real Estate \& Property Management, Energy \& Sustainability Management, Project Management, Workplace Management, and Facilities Services Management. In some cases, it can be seen in Table 1 that some elements of the matrix appear empty because the document did not show an area similar to that of the guide document. Instead, other elements could have one or more areas similar to those of the guidance document. This confirms that most of the proposed areas of the FM are related to the areas exposed by the authors of the literature review. 
Table 1. Compilation of proposals from FM areas in the literature review.

\begin{tabular}{|c|c|c|c|c|c|c|}
\hline \multirow[b]{2}{*}{ Doc. } & \multicolumn{6}{|c|}{ FACILITY MANAGEMENT AREAS } \\
\hline & $\begin{array}{c}\text { ASSET \& } \\
\text { MAINTENANCE } \\
\text { MANAGEMENT }\end{array}$ & $\begin{array}{c}\text { REAL ESTATE \& } \\
\text { PROPERTY } \\
\text { MANAGEMENT }\end{array}$ & $\begin{array}{c}\text { ENERGY \& } \\
\text { SUITANABILITY } \\
\text { MANAGEMENT }\end{array}$ & $\begin{array}{c}\text { PROJECT } \\
\text { MANAGEMENT }\end{array}$ & $\begin{array}{l}\text { WORKPLACE } \\
\text { MANAGEMENT }\end{array}$ & $\begin{array}{l}\text { FACILITIES } \\
\text { SERVICES } \\
\text { MANAGEMENT }\end{array}$ \\
\hline $\begin{array}{c}(\text { Cotts \& } \\
\text { Lee, 1992) }\end{array}$ & $\begin{array}{c}\text { Operation } \\
\text { Maintenance and } \\
\text { Repair \& } \\
\text { Budgeting } \\
\text { Accounting and } \\
\text { Economics \& } \\
\text { Facility Planning } \\
\text { and } \\
\text { Forecasting }\end{array}$ & $\begin{array}{l}\text { Corporate Real } \\
\text { Estate } \\
\text { Management \& } \\
\text { Management of } \\
\text { Organization }\end{array}$ & & $\begin{array}{l}\text { Construction } \\
\text { Project } \\
\text { Management }\end{array}$ & $\begin{array}{c}\text { Alteration } \\
\text { Renovation and } \\
\text { Workplace }\end{array}$ & $\begin{array}{c}\text { General } \\
\text { Administration of } \\
\text { Services \& } \\
\text { Security and Life- } \\
\text { Safety } \\
\text { Management }\end{array}$ \\
\hline $\begin{array}{c}\text { (IFMA, } \\
\text { 1992) }\end{array}$ & $\begin{array}{l}\text { Operations and } \\
\text { Maintenance \& } \\
\text { Financial } \\
\text { Management }\end{array}$ & $\begin{array}{l}\text { Real Estate and } \\
\text { Strategic Planning }\end{array}$ & & $\begin{array}{l}\text { Planning and } \\
\text { Project } \\
\text { Management }\end{array}$ & $\begin{array}{l}\text { Human and } \\
\text { Environmental } \\
\text { Factors }\end{array}$ & $\begin{array}{c}\text { Communication \& } \\
\text { Quality } \\
\text { Assessment and } \\
\text { Innovation }\end{array}$ \\
\hline $\begin{array}{l}\text { (Then, } \\
\text { 1994) }\end{array}$ & $\begin{array}{c}\text { Asset \& } \\
\text { Information } \\
\text { Management }\end{array}$ & $\begin{array}{c}\text { Strategic } \\
\text { Management }\end{array}$ & & $\begin{array}{c}\text { Change } \\
\text { Management }\end{array}$ & & $\begin{array}{c}\text { Service \& People } \\
\text { Management }\end{array}$ \\
\hline $\begin{array}{c}\text { (Jones \& } \\
\text { Hunter, } \\
\text { 1995) }\end{array}$ & $\begin{array}{l}\text { Operation and } \\
\text { Maintenance }\end{array}$ & $\begin{array}{l}\text { Real Estate and } \\
\text { Financial } \\
\text { Management }\end{array}$ & & $\begin{array}{l}\text { Renovation } \\
\text { Rebuild and } \\
\text { Expansion }\end{array}$ & $\begin{array}{c}\text { Spatial \& } \\
\text { Customer } \\
\text { Management }\end{array}$ & \\
\hline $\begin{array}{l}\text { (Svensson, } \\
\text { 1998) }\end{array}$ & $\begin{array}{c}\text { Financial } \\
\text { Management }\end{array}$ & $\begin{array}{l}\text { Corporate Real } \\
\text { Estate } \\
\text { Management }\end{array}$ & Utilities Supplies & $\begin{array}{l}\text { Building \& } \\
\text { Change } \\
\text { Management }\end{array}$ & $\begin{array}{c}\text { Human Resources } \\
\text { Management }\end{array}$ & $\begin{array}{c}\text { Contract \& } \\
\text { Security and Life- } \\
\text { Safety } \\
\text { Management \& } \\
\text { Domestic Services }\end{array}$ \\
\hline $\begin{array}{l}\text { (Atkin \& } \\
\text { Brooks, } \\
\text { 2000) }\end{array}$ & $\begin{array}{l}\text { Asset \& Corporate } \\
\text { Resources \& } \\
\text { Technology \& } \\
\text { Finance } \\
\text { Management }\end{array}$ & $\begin{array}{l}\text { Organization } \\
\text { Strategy }\end{array}$ & & Logistics & $\begin{array}{l}\text { Workplace \& } \\
\text { Human } \\
\text { Management }\end{array}$ & $\begin{array}{c}\text { Business Support } \\
\text { Services }\end{array}$ \\
\hline $\begin{array}{l}\text { (Varcoe, } \\
2000)\end{array}$ & $\begin{array}{l}\text { Maintenance and } \\
\text { Operation of the } \\
\text { Physical Plant \& } \\
\text { Long-Range and } \\
\text { Annual Facility } \\
\text { Planning \& } \\
\text { Facility Financial } \\
\text { Forecasting and } \\
\text { Management \& } \\
\text { Telecommunicatio } \\
\text { n }\end{array}$ & $\begin{array}{c}\text { Real Estate } \\
\text { Acquisition and/or } \\
\text { Disposal }\end{array}$ & & $\begin{array}{c}\text { New } \\
\text { Construction } \\
\text { and/or } \\
\text { Renovation Works }\end{array}$ & $\begin{array}{c}\text { Interior Space } \\
\text { Planning \& Space } \\
\text { Management }\end{array}$ & $\begin{array}{c}\text { Security \& } \\
\text { General } \\
\text { Administrative } \\
\text { Services }\end{array}$ \\
\hline
\end{tabular}




\begin{tabular}{|c|c|c|c|c|c|c|}
\hline $\begin{array}{l}\text { (Lee, } \\
2002)\end{array}$ & $\begin{array}{l}\text { Maintenance and } \\
\text { Repairs \& } \\
\text { Planning and } \\
\text { Programming }\end{array}$ & $\begin{array}{l}\text { Corporate and } \\
\text { Property } \\
\text { Management }\end{array}$ & & $\begin{array}{c}\text { Facility Project } \\
\text { Management }\end{array}$ & $\begin{array}{c}\text { Space Planning } \\
\text { and Management } \\
\& \text { Work } \\
\text { Specifications and } \\
\text { Installation }\end{array}$ & $\begin{array}{c}\text { Building Services } \\
\text { and Operations \& } \\
\text { Office Services \& } \\
\text { Employee and } \\
\text { Services }\end{array}$ \\
\hline $\begin{array}{l}\text { (Chotipani } \\
\text { ch, 2004) }\end{array}$ & $\begin{array}{l}\text { Finance \& } \\
\text { Operations and } \\
\text { Maintenance \& } \\
\text { Application } \\
\text { Management }\end{array}$ & $\begin{array}{l}\text { Asset and Property } \\
\text { Management }\end{array}$ & $\begin{array}{c}\text { Utility } \\
\text { Management }\end{array}$ & & & $\begin{array}{c}\text { Auxiliary Services } \\
\text { Management }\end{array}$ \\
\hline $\begin{array}{l}\text { (De Toni, } \\
\text { Fornasier } \\
\text { \& Nonino, } \\
\text { 2006) }\end{array}$ & $\begin{array}{l}\text { Operational \& } \\
\text { Finance } \\
\text { Management }\end{array}$ & & & & $\begin{array}{c}\text { Space \& } \\
\text { Behavior } \\
\text { Management }\end{array}$ & \\
\hline $\begin{array}{l}\text { (Banyani } \\
\text { \& Then, } \\
\text { 2010) }\end{array}$ & Technic Services & Real Estate & & $\begin{array}{c}\text { Project } \\
\text { Management }\end{array}$ & $\begin{array}{c}\text { Space } \\
\text { Management }\end{array}$ & Support Services \\
\hline $\begin{array}{l}\text { (Ive, } \\
2011)\end{array}$ & $\begin{array}{l}\text { Financial \& } \\
\text { Record } \\
\text { Management }\end{array}$ & & $\begin{array}{c}\text { Environmental } \\
\text { Management }\end{array}$ & & $\begin{array}{c}\text { Space } \\
\text { Management }\end{array}$ & $\begin{array}{c}\text { Facilities Services } \\
\text { Management }\end{array}$ \\
\hline $\begin{array}{c}\text { (ProFM, } \\
\text { 2018) }\end{array}$ & $\begin{array}{l}\text { Operation and } \\
\text { Maintenance }\end{array}$ & $\begin{array}{c}\text { Business } \\
\text { Management }\end{array}$ & & $\begin{array}{c}\text { Asset } \\
\text { Management * }\end{array}$ & & Risk Management \\
\hline $\begin{array}{l}\text { (IFMA- } \\
\text { Spain, } \\
\text { 2019) }\end{array}$ & & $\begin{array}{l}\text { Real Estate } \\
\text { Services }\end{array}$ & & $\begin{array}{c}\text { Project } \\
\text { Management }\end{array}$ & & $\begin{array}{l}\text { Personal \& } \\
\text { Corporative } \\
\text { Services }\end{array}$ \\
\hline $\begin{array}{l}\text { (Castro \& } \\
\text { Plaza, } \\
\text { 2019) }\end{array}$ & $\begin{array}{c}\text { Asset } \\
\text { Management }\end{array}$ & $\begin{array}{l}\text { Corporate Real } \\
\text { Estate } \\
\text { Management }\end{array}$ & $\begin{array}{l}\text { Sustainability } \\
\text { Management }\end{array}$ & $\begin{array}{c}\text { Project } \\
\text { Management }\end{array}$ & $\begin{array}{c}\text { Workplace } \\
\text { Management }\end{array}$ & $\begin{array}{c}\text { People Services } \\
\text { Management }\end{array}$ \\
\hline
\end{tabular}

(*) Although the name of this area is Asset Management, the content is totally linked to Project Management functions; that is why it has been accommodated in this area.

Later, the authors of this work created another matrix (Table 2), in which the functions of the FMer that they identified in the selected documents were accommodated, maintaining the same order in the new areas proposed in Table 1. In this matrix, some functions of the selected documents were introduced according to the areas proposed by the guide document; in some cases, the elements of the matrix appeared empty because the functions did not show similarity with the proposed areas, and in other cases, the elements of the matrix appeared with more than one function. In addition, those functions of the selected documents that did not correspond to the proposed areas were discarded to avoid confusion, and, therefore, in Table 2, only those functions that belong to the aforementioned proposed area are found. 
Table 2. Compilation of proposals for FM functions in the literature review.

\begin{tabular}{|c|c|c|c|c|c|c|}
\hline \multirow[b]{2}{*}{ Doc. } & \multicolumn{6}{|c|}{ FACILITY MANAGEMENT AREAS } \\
\hline & $\begin{array}{c}\text { ASSET \& } \\
\text { MAINTENANCE } \\
\text { MANAGEMENT }\end{array}$ & $\begin{array}{l}\text { REAL ESTATE } \\
\text { \& PROPERTY } \\
\text { MANAGEMENT }\end{array}$ & $\begin{array}{c}\text { ENERGY \& } \\
\text { SUITANABILITY } \\
\text { MANAGEMENT }\end{array}$ & $\begin{array}{c}\text { PROJECT } \\
\text { MANAGEMENT }\end{array}$ & $\begin{array}{l}\text { WORKPLACE } \\
\text { MANAGEMENT }\end{array}$ & $\begin{array}{l}\text { FACILITIES } \\
\text { SERVICES } \\
\text { MANAGEMENT }\end{array}$ \\
\hline $\begin{array}{l}\text { (Banyani } \\
\text { \& Then, } \\
\text { 2010) }\end{array}$ & $\begin{array}{c}\text { Asset } \\
\text { Management; } \\
\text { Maintenance and } \\
\text { Renovation; } \\
\text { Investment } \\
\text { Management }\end{array}$ & & & & $\begin{array}{c}\text { Design; } \\
\text { Utilization; Exit } \\
\text { and Relocation } \\
\text { Form; Human } \\
\text { Resources } \\
\text { Management } \\
\text { (Satisfaction); } \\
\text { Users' Perception; } \\
\text { Participation of } \\
\text { Users }\end{array}$ & \\
\hline $\begin{array}{l}\text { (UNE, } \\
2012)\end{array}$ & & $\begin{array}{l}\text { Strategic Planning; } \\
\text { Rental } \\
\text { Management }\end{array}$ & $\begin{array}{l}\text { Energy and } \\
\text { Facilities } \\
\text { Management; } \\
\text { Sustainability } \\
\text { management; } \\
\text { Lighting } \\
\text { Maintenance; Toxic } \\
\text { Waste Management }\end{array}$ & & $\begin{array}{l}\text { Design and } \\
\text { Ergonomics in the } \\
\text { Workspace; } \\
\text { Furniture } \\
\text { Selection; Internal } \\
\text { and external } \\
\text { Equipment; } \\
\text { Signaling, } \\
\text { Decoration, } \\
\text { Sharing and } \\
\text { Replacement of } \\
\text { Furniture }\end{array}$ & $\begin{array}{l}\text { Hygiene Services; } \\
\text { Cleaning of } \\
\text { Workspace and } \\
\text { Equipment; } \\
\text { Cleaning of the } \\
\text { Textile Material } \\
\text { and Glazing of the } \\
\text { Building; Supply } \\
\text { and Maintenance } \\
\text { of Cleaning } \\
\text { Equipment; } \\
\text { Cleaning of } \\
\text { External Areas and } \\
\text { Stationary Services }\end{array}$ \\
\hline $\begin{array}{l}\text { (UNE, } \\
2012)\end{array}$ & $\begin{array}{c}\text { Data and } \\
\text { Telephone } \\
\text { Network } \\
\text { Operations; Data } \\
\text { centers, Central } \\
\text { Server Hosting, } \\
\text { and Related } \\
\text { Services; Support } \\
\text { of Personal } \\
\text { Computers; IT } \\
\text { Security and } \\
\text { Protection; } \\
\text { Informatic, } \\
\text { Telephonic and } \\
\text { Portability } \\
\text { Connections }\end{array}$ & & & $\begin{array}{c}\text { Project } \\
\text { Management }\end{array}$ & & $\begin{array}{l}\text { Internal Mail and } \\
\text { Messaging; } \\
\text { Reprography; } \\
\text { Office Supplies; } \\
\text { Shipping and } \\
\text { Storage systems; } \\
\text { People } \\
\text { Transportation and } \\
\text { Travel; Vehicle } \\
\text { Parking and Fleet } \\
\text { Management; } \\
\text { Reception and } \\
\text { Secretariat; } \\
\text { Catering and } \\
\text { Vending } \\
\text { Machines; } \\
\text { Organization of } \\
\text { Conferences, } \\
\text { Meetings and } \\
\text { Events; Personal } \\
\text { Services; Provision } \\
\text { of Work Clothing; } \\
\text { Access Control, } \\
\text { Smart } \\
\text { Identification } \\
\text { Cards, Locks and } \\
\text { Key Custodians, } \\
\text { etc.; Security and } \\
\text { Fire Protection; } \\
\text { Risk Prevention } \\
\text { Services; Physical } \\
\text { Security } \\
\text { Management }\end{array}$ \\
\hline
\end{tabular}




\begin{tabular}{|c|c|c|c|c|c|c|}
\hline $\begin{array}{l}\text { (Ive, } \\
2011 \text { ) }\end{array}$ & $\begin{array}{l}\text { Maintenance } \\
\text { management; } \\
\text { Implementation of } \\
\text { the CMMS; } \\
\text { Centralized Control } \\
\text { System }\end{array}$ & $\begin{array}{l}\text { Building Contract } \\
\text { Management; } \\
\text { Location Search; } \\
\text { Acquisitions and } \\
\text { Sales; Property } \\
\text { Evaluation; } \\
\text { Property- } \\
\text { Condominium } \\
\text { Relationship } \\
\text { Management; } \\
\text { Control of Rates } \\
\text { and Property } \\
\text { conditions }\end{array}$ & & $\begin{array}{c}\text { Project } \\
\text { Management; } \\
\text { Feasibility Studies; } \\
\text { Design; Tender } \\
\text { Management; } \\
\text { Operational } \\
\text { Planning; } \\
\text { Construction } \\
\text { Management }\end{array}$ & $\begin{array}{l}\text { Building Analysis; } \\
\text { Planning of } \\
\text { Spaces; } \\
\text { Measurement and } \\
\text { Categorization of } \\
\text { Spaces (CAD); } \\
\text { File and Design } \\
\text { update (CAD); } \\
\text { Redesign of } \\
\text { Spaces }\end{array}$ & $\begin{array}{l}\text { Management of } \\
\text { Support Services } \\
\text { (Reception, } \\
\text { Surveillance, } \\
\text { Events, } \\
\text { Disinfection, } \\
\text { Cleaning, Catering, } \\
\text { Waste, Messaging } \\
\text {... Others) Events; } \\
\text { Licensing and } \\
\text { Permissions } \\
\text { Management; } \\
\text { Security; Fleet } \\
\text { Management }\end{array}$ \\
\hline $\begin{array}{c}\text { (ProFM, } \\
2018)\end{array}$ & Technical services & $\begin{array}{c}\text { Property; } \\
\text { Acquisitions }\end{array}$ & & $\begin{array}{l}\text { Construction } \\
\text { Project } \\
\text { Management }\end{array}$ & & $\begin{array}{c}\text { Compliance and } \\
\text { Standards, Safety, } \\
\text { Health and } \\
\text { Environmental; } \\
\text { Security; } \\
\text { Emergency } \\
\text { Management }\end{array}$ \\
\hline $\begin{array}{l}\text { (IFMA- } \\
\text { Spain, } \\
2019)\end{array}$ & & $\begin{array}{c}\text { Strategy; } \\
\text { Transactions (rent } \\
\text { and inversion); } \\
\text { Ratings; } \\
\text { Consultancy }\end{array}$ & & $\begin{array}{l}\text { Construction } \\
\text { Management; } \\
\text { Remodeling; } \\
\text { Removals; Project } \\
\text { Management (int. } \\
\text { y ext.) }\end{array}$ & & $\begin{array}{c}\text { Management of } \\
\text { Support Services } \\
\text { (Reception, } \\
\text { Surveillance, } \\
\text { Events, } \\
\text { Disinfection, } \\
\text { Cleaning, Catering, } \\
\text { Waste, Messaging } \\
\text { ‥ Others); Travels; } \\
\text { Fleets; Safety and } \\
\text { Hygiene }\end{array}$ \\
\hline $\begin{array}{l}\text { (Castro } \\
\text { \& Plaza, } \\
\text { 2019) }\end{array}$ & $\begin{array}{c}\text { Life Cycle } \\
\text { Management; IT } \\
\text { Management; } \\
\text { Building } \\
\text { Management } \\
\text { System; BIM } \\
\text { Management; } \\
\text { Maintenance } \\
\text { Management }\end{array}$ & $\begin{array}{c}\text { Business } \\
\text { Continuity; } \\
\text { Portfolio } \\
\text { Management; } \\
\text { Property } \\
\text { Management; Risk } \\
\text { Management; } \\
\text { Legal Affairs } \\
\text { Management }\end{array}$ & $\begin{array}{c}\text { Energy } \\
\text { Management; } \\
\text { Sustainability } \\
\text { Management - CSR; } \\
\text { Accreditation in } \\
\text { Sustainability }\end{array}$ & $\begin{array}{l}\text { Construction } \\
\text { Management; } \\
\text { Relocation } \\
\text { Management; } \\
\text { Removal } \\
\text { Management; } \\
\text { Migration } \\
\text { Management }\end{array}$ & $\begin{array}{l}\text { Asset Management } \\
\text { in the Work } \\
\text { Environment; } \\
\text { Documentation } \\
\text { Management }\end{array}$ & $\begin{array}{c}\text { Services } \\
\text { Management; } \\
\text { Property Services } \\
\text { Management; } \\
\text { Security } \\
\text { Management; } \\
\text { Security and health } \\
\text { at work; Events }\end{array}$ \\
\hline
\end{tabular}

\section{Proposal of Functions and Their Classification}

The authors of this work merged the FMer functions that appear in each element of the matrix (Table 2) to create the provisional list of functions to be validated by the experts. The work obtained from the analysis of the literature review (Table 1 and Table 2) proposes a provisional list (Table 3) with 38 functions of the FMer and classifies them in the 6 main areas of the FM according to the guide document. 
Table 3. List of proposed functions that comprise the FM profession for consulting experts.

\begin{tabular}{|c|c|c|}
\hline $\begin{array}{l}\text { Asset \& Maintenance } \\
\text { Management }\end{array}$ & $\begin{array}{l}\text { Real Estate and Property } \\
\text { Management }\end{array}$ & Workplace Management \\
\hline Life Cycle Management & Emergency Management & Space Management and Planning \\
\hline Technology Management & Portfolio Management & $\begin{array}{l}\text { Work Environment Space } \\
\text { Management }\end{array}$ \\
\hline $\begin{array}{l}\text { Building Management System } \\
\text { (BMS) }\end{array}$ & Property Management & $\begin{array}{l}\text { Organizational Culture } \\
\text { Management }\end{array}$ \\
\hline $\begin{array}{l}\text { Building Information Modeling } \\
\text { (BIM) }\end{array}$ & Management and Leadership & Human Capital Management \\
\hline Maintenance Management & Risk Management & Document Management \\
\hline Resource Management & Legal Affairs Management & Facilities Services Management \\
\hline Financial Management & $\begin{array}{l}\text { Business Continuity } \\
\text { Management }\end{array}$ & $\begin{array}{l}\text { Occupational Risk Prevention } \\
\text { Management }\end{array}$ \\
\hline Project Management & Organizational Strategic Plan & Security Management \\
\hline Project Management (Int./Ext.) & $\begin{array}{l}\text { Energy \& Sustainability } \\
\text { Management }\end{array}$ & Contract Management \\
\hline Construction Management & Energy Management & Performance Management \\
\hline Relocation Management & Supply Management (Utilities) & Communication Management \\
\hline Removal Management & Sustainability Management & Event Management \\
\hline Migration Management & $\begin{array}{l}\text { Corporate Social Responsibility } \\
\text { Management }\end{array}$ & $\begin{array}{l}\text { Support Services Management } \\
\text { (Cleaning, Technicians, }\end{array}$ \\
\hline Change Management & $\begin{array}{l}\text { Accreditation in Sustainability, } \\
\text { Energy, Quality, HSE, CSR and } \\
\text { others }\end{array}$ & $\begin{array}{l}\text { Surveillance, Waste, Messaging, } \\
\text { Catering, Waste, among others) }\end{array}$ \\
\hline
\end{tabular}

\section{Expert Consultation}

Based on the development of the proposal set out in Table 3, an invitation was made to 35 professional specialists linked professionally or academically to the FM profession in Latin America. Seventeen of them were accepted for participation in the completion of the electronic questionnaires by email. The delimitation of FM experts from Latin 
America has been because culturally the response is more homogeneous than if it had been carried out on different continents because of the ease of use a single language.

On the one hand, the 17 Latin American experts consulted come from the following eight countries: Colombia, Argentina, Brazil, Peru, Mexico, Chile, Panama, and Uruguay. The most representative professions in this expert group are engineers, architects, administrators, and one graduated in chemistry. Most of these FMer (67\%) have more than 15 years of experience in FM, 23\% have between 10 and 15 years, and the rest (12\%) have between 5 and 10 years of experience. In addition, the experience at different levels of management performed in the FM was high or very high $(>8)$. The partial validation of the experience in FM by the experts consulted was greater than 0.8 (Table 4); therefore, the partial results (Kc) obtained exceeded the limitations imposed for the selection of experts by Cabero \& Barroso (2013).

On the other hand, the partial validation of the competencies in FM of the experts consulted offers varying results in the different sections shown in Table 4. The results of all the experts indicate that they have medium and high competencies for theoretical analysis of FM, as well as in the general competences of the FM. Furthermore, the professional experience of FM in different industrial sectors is medium and high, and the knowledge of the performance of the FM abroad and the experience is medium and high. Although most of the consultants present a high interaction with other FMer nationally or internationally, and only a few present a low interaction, this information indicates that the partial validation of FM competencies by those consulted is high (Ka), and, finally, the results of the validation of the experts consulted have exceeded the limitations imposed by the selection of experts from Cabero \& Barroso (2013). In Table 4, it can be observed that, in the last column (K), all the experts have a high coefficient of competence, with results equal to or greater than 0.8 ; and thus, they are suitable to carry out this query to offer different levels of information and argumentation (Brown \& Katz, 2011).

Table 4. Partial Coefficients of FM experience (Kc), partial coefficient of competences in FM (Ka) and total coefficient of validation of experts $(\mathrm{K})$.

\begin{tabular}{|c|c|c|c|c|c|c|c|c|c|c|}
\hline 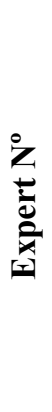 & 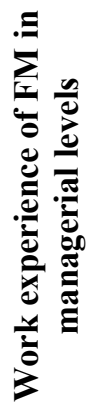 & 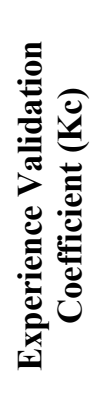 & 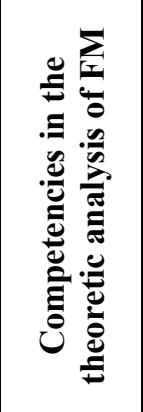 & 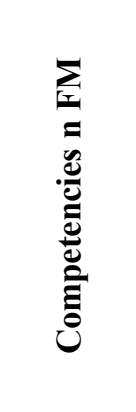 & 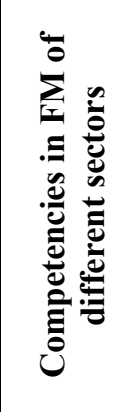 & 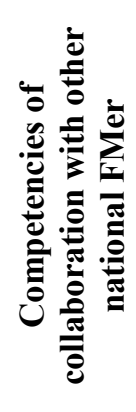 & 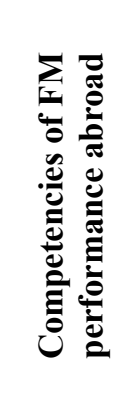 & 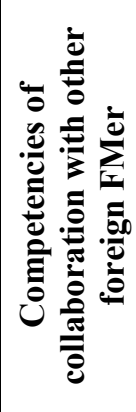 & 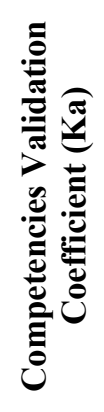 & Uُ \\
\hline 1 & 8 & 0,8 & Medium & Medium & High & Low & Medium & Low & 0,725 & 0,8 \\
\hline 2 & 8 & 0,8 & Medium & High & High & Medium & Medium & Medium & 0,855 & 0,8 \\
\hline 3 & 8 & 0,8 & Medium & High & Medium & Medium & Medium & Medium & 0,84 & 0,8 \\
\hline 4 & 10 & 1 & High & High & High & High & High & High & 1 & 1,0 \\
\hline 5 & 8 & 0,8 & Medium & High & High & Medium & Medium & Low & 0,84 & 0,8 \\
\hline 6 & 9 & 0,9 & High & High & High & High & High & High & 0,985 & 0,9 \\
\hline 7 & 9 & 0,9 & High & High & High & High & High & High & 1 & 1,0 \\
\hline
\end{tabular}




\begin{tabular}{|c|c|c|c|c|c|c|c|c|c|c|}
\hline 8 & 10 & 1 & High & High & Medium & High & Medium & Medium & 0,955 & $\mathbf{1 , 0}$ \\
\hline 9 & 8 & 0,8 & Medium & High & Medium & High & Medium & High & 0,87 & $\mathbf{0 , 8}$ \\
\hline 10 & 8 & 0,8 & High & High & Medium & High & Medium & Low & 0,94 & $\mathbf{0 , 9}$ \\
\hline 11 & 8 & 0,8 & High & Medium & High & Medium & High & High & 0,77 & $\mathbf{0 , 8}$ \\
\hline 12 & 10 & 1 & High & High & High & High & Medium & Medium & 0,97 & $\mathbf{1 , 0}$ \\
\hline 13 & 9 & 0,9 & High & High & High & High & High & High & 1 & $\mathbf{1 , 0}$ \\
\hline 14 & 8 & 0,8 & High & High & High & Medium & Medium & Medium & 0,955 & $\mathbf{0 , 9}$ \\
\hline 15 & 8 & 0,8 & High & High & High & High & High & High & 1 & $\mathbf{0 , 9}$ \\
\hline 16 & 8 & 0,8 & Medium & High & High & High & Medium & Medium & 0,87 & $\mathbf{0 , 8}$ \\
\hline 17 & 8 & 0,8 & High & High & High & High & High & High & 1 & $\mathbf{0 , 9}$ \\
\hline
\end{tabular}

According to several authors (Gordon, 1994; Witkin \& Altschuld, 1995; García \& Fernández, 2008), this group of participating experts constitutes a focus group with a disinterested purpose and objective in the development of a consultation by expert judgment. Under no circumstances, the authors of this work assume that the responses of this group are representative of the community of Latin American FM professionals, but this group allows verifications and validations, with descriptive fidelity by statistical consensus (Piñeiro, 2003). In addition, qualitative information has been obtained through private opinions and valuable comments on the consultation (Vanegas, 2011).

The results of the second part of the questionnaire on the acceptance of the proposal of the functions of the FMer and their classification, in the only round of consultation, are presented as follows (Table 5):

a) The acceptance of the proposal of 6 areas in the FM: in this option, twelve of the experts consulted (70.5\%) approved that this proposal represents the majority of the support activities. Some of the 12 experts proposed other functions, which did not reach 50\% approval (Table 5). Only two of the proposals were considered for analysis in an upcoming future FMer functions proposal: design thinking and user experience.

b) The acceptance of the proposal of 6 areas in the FM plus the inclusion of others: in this option, four of the experts consulted $(23.5 \%)$ exposed that this proposal did not represent all the support activities. Each of the experts presented several functions of the FMer in addition to those proposed in Table 3, as well as 2 more areas where they can be classified. In this section, only three functions from Table 4 were not approved by the four experts with more than 50\% acceptance (Table 5): Emergency Management, Documentation Management, and Security Management. Nonetheless, there is the possibility of considering in a future consultation a new area for Technology Management, in which the following functions can be fitted: Building Information Modeling, Building Management System, Internet of Things, Virtual Reality, Augmented Reality, Artificial Intelligence, among others.

c) The approach of a different proposal on the FM's areas: in this option, one of the experts (6\%) consulted proposed another way of distributing the main areas and functions that represent the support activities. The only expert who proposed a new configuration of the FM areas, as well as the linkage of the functions to those areas, was interpreted by the authors as an outlier (Table 5). However, it is not discarded for the general computation although 16 responses still provide an acceptable estimate for content validity according to several authors (Gordon, 1994; Witkin \& Altschuld, 1995; García \& Fernández, 2008). 
Table 5. Approval of the areas of the FM and the functions of the FMer.

\begin{tabular}{|c|c|c|c|c|c|c|c|c|c|}
\hline \multirow{2}{*}{$\begin{array}{l}\text { Expert } \\
\mathbf{N}^{\mathbf{0}}\end{array}$} & \multicolumn{3}{|c|}{ Approval of 6 proposed areas } & \multicolumn{6}{|c|}{$\begin{array}{l}\text { Approval of FMer functions in each area } \\
\qquad(>\mathbf{5 0 \%})\end{array}$} \\
\hline & Option A & Option B & Option C & AMM & PRM & ESM & СРM & $\mathbf{W M}$ & FSM \\
\hline 1 & YES & & & YES & YES & YES & YES & YES & YES \\
\hline 2 & YES & & & YES & YES & YES & YES & YES & YES \\
\hline 3 & YES & & & YES & YES & YES & YES & YES & YES \\
\hline 4 & & YES & & YES & YES & YES & YES & YES & YES \\
\hline 5 & YES & & & YES & YES & YES & YES & YES & YES \\
\hline 6 & YES & & & YES & YES & YES & YES & YES & YES \\
\hline 7 & & YES & & YES & NO & YES & NO & YES & YES \\
\hline 8 & & & NO & $\mathrm{NO}$ & $\mathrm{NO}$ & NO & $\mathrm{NO}$ & NO & $\mathrm{NO}$ \\
\hline 9 & YES & & & YES & YES & YES & YES & YES & YES \\
\hline 10 & & YES & & YES & YES & YES & YES & YES & YES \\
\hline 11 & YES & & & YES & YES & YES & YES & YES & YES \\
\hline 12 & YES & & & YES & YES & YES & YES & YES & YES \\
\hline 13 & YES & & & YES & YES & YES & YES & YES & YES \\
\hline 14 & YES & & & YES & YES & YES & YES & YES & YES \\
\hline 15 & & YES & & YES & YES & YES & YES & YES & YES \\
\hline 16 & YES & & & YES & YES & YES & YES & YES & YES \\
\hline 17 & YES & & & YES & YES & YES & YES & YES & YES \\
\hline Partial & $70,50 \%$ & $23,50 \%$ & $6,00 \%$ & $94 \%$ & $88 \%$ & $94 \%$ & $88 \%$ & $94 \%$ & $94 \%$ \\
\hline Total & & $94 \%$ & & & & & & & \\
\hline
\end{tabular}

Thus, the authors of this work made the decision to integrate the results of sections a) and b) to obtain the acceptance great majority of the functions proposed in each of the 6 main areas of the FM. In other words, the 6 main areas of the FM proposed in Table 3 are accepted by a majority (94\%). On the other hand, most of the functions proposed in Table 3 were approved, with an acceptance greater than $50 \%$, except for the function called 
Documentation Management. Consequently, the final approved list of FM functions consists of 37 different occupations associated with the 6 main areas of the FM as shown in Fig. 2.

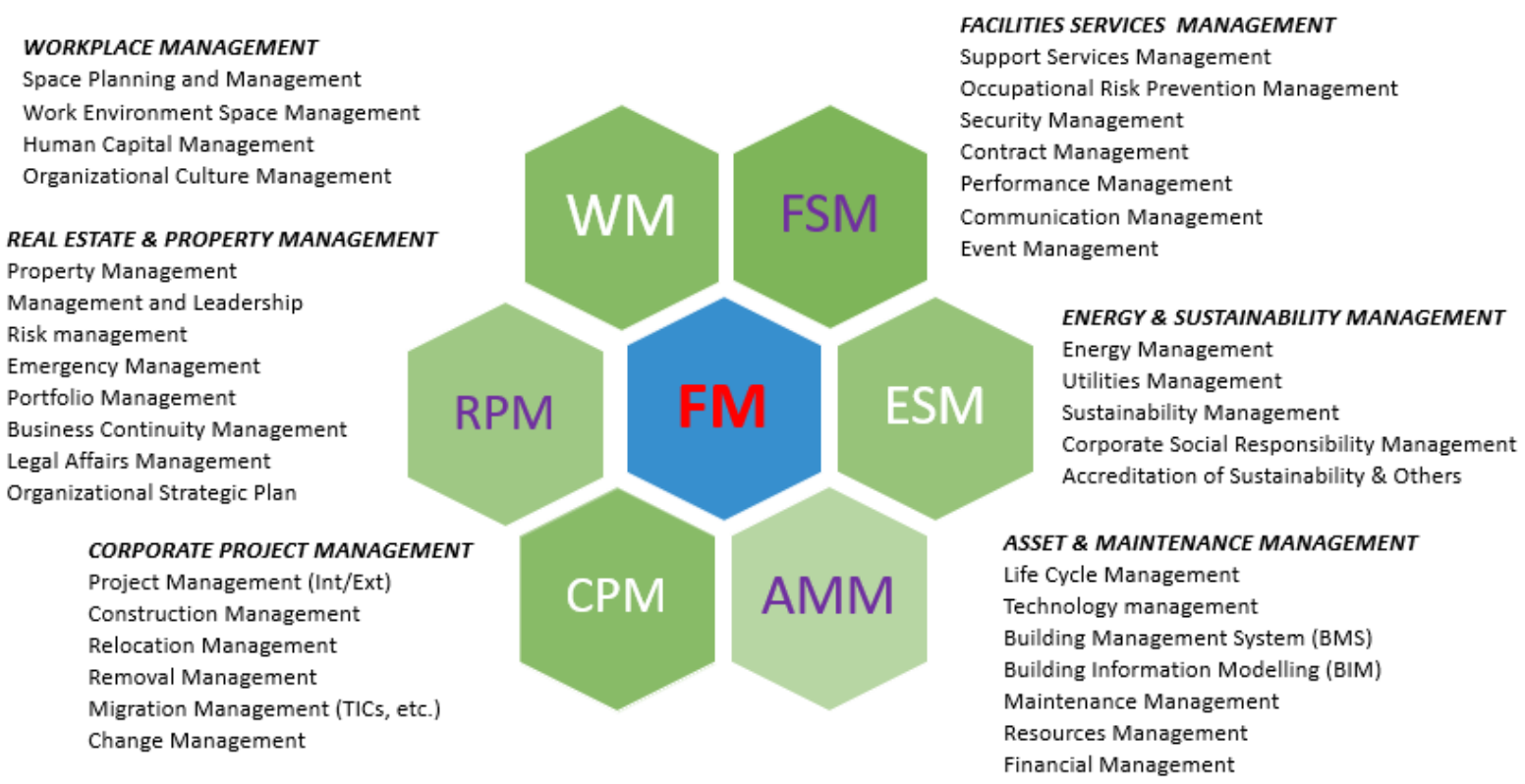

Figure 2. Proposed functions of FM profession according to experts' validation.

Despite the fact that more than $94 \%$ of the proposed functions were approved, the authors of this work deduced that the relative low qualification of the function called Documentation Management is due to the fact that there is not an explicit agreement with the contemporary uses of organizations regarding Documentation Management, or also called Knowledge Management (KM), which is associated with the Workplace Management area. In the context of this research work, a particular GC approach associated with Intellectual Capital Management (ICM) is assumed, which is based on three basic pillars independent of the model used or adapted by an organization: the Directory of Experts, the Communities of Practice, and Documental Management. In the consultation process, a feedback was provided to the experts with the information of the results obtained (Figure 2) and asked for their opinion on the nonacceptance of the Documentation Management function, and even the hypothetical link to any of the approved FM areas. The authors of this work deduced from the answers issued by some of the experts that the KM function is transversal to the entire organization, such as Quality or Continuous Improvement, and, therefore, it is difficult to locate it in one main area of the FM.

The authors of this work valued that the development of functions of the FMer and their classification in different main areas of the FM can vary significantly in each organization depending on the country, the type of company, and the industrial sector. However, the limitation of this research has been the difficulty of establishing search equations in metasearch engines in order to have a better identification and analysis of the texts, in order to further argue the two proposals (functions and areas). Consequently, it follows that this work does not include the full spectrum of functions related to the performance of the FMer existing in the literature, nor all those that are currently used in each of the organizations at an international level. Meanwhile, the authors of this work consider it opportune for future research on the functions of the FMer and its classification that the compilation of the functions of the FMer is not only through the literature and looks like the carried out by the IFMA for the management basic competencies of the FM (Castellanos-Moreno, 2013). 


\section{CONCLUSION}

The proposal validated by Latin American experts on the functions of the FMer and its classification in main areas has allowed us to collect information from secondary sources of the discipline and fit them into the vision of the practitioners of this profession. This work has shown the different approaches to the role of this 'broker' that helps support the main activity of an organization over the last decades. This proposal adjusts to the evolution of FM today with a more strategic approach without losing the relationship between the management of people, space, technology, and the process of the support activities of an organization. Furthermore, the approval with $94 \%$ of the experts of the 37 functions of the FMer and their classification in the 6 main areas of the FM exposed in the results can be considered sufficiently robust. Above all, the vision of Latin American experts' consultation on this proposal strengthens the FM as a profession of the future to underpin the support activities of organizations through multidisciplinary groups. Inclusively, this work could be the basis of a series of researches at national or international level that show the evolution and/or updating of the functions to be performed by FM practitioners and, in turn, allow delimiting the responsibilities and roles of the FMer in their organizations.

However, it is necessary to learn from the limitations of this work in order to improve the search for results in future reviews of the literature, to be able to achieve a greater number of experts in a future validation and to develop a more flexible questionnaire to accommodate the functions suggested by the experts. Furthermore, in future works, the authors of this document recommend guiding the participants on the difference between activities, functions, areas, competencies, and roles within FM. Likewise, a closer collaboration with FM professional associations would be necessary for a global investigation, which identifies the functions of the FMer and areas of FM derived from the literature that are currently performed on organizations in different industrial sectors.

\section{ACKNOWLEDGMENT}

The authors thank the people that helped in translating the abstract into Arabic and Latin American FM experts who have participated in this consultation. Additionally, the authors wish to thank the CIDI research program of the Pontificia Bolivariana University (Medellín) for the support of research.

\section{REFERENCES}

APPA, 2002. Development of the Facility Management Profession. Alexandria: Association of Higher Education Facilities Officer.

Atkin, B. \& Brooks, A., 2000. Total Facilities Management. London: Blackwell Science.

Banyani, M., \& Then, S.S., 2010. A model for assessing the maturity of facility management as an industry sector. Proceedings of CIB W70 International Conference in Facilities Management, FM in the Experience Economy, Sao Paulo, 13-15 September 2010, p. 99-110.

Brown, T., \& Katz, B., 2011. Change by design. Journal of product innovation management, 28(3), p. 381-383.

Cabero, J. \& Barroso, J., 2013. La utilización del juicio de experto para la evaluación de TIC: el Coeficiente de competencia experta. Bordón. Revista de Pedagogía, 65(2), 25-38.

Castellanos-Moreno, M., 2013. La responsabilidad social como valor añadido del facilities manager en la gestión del patrimonio inmobiliario. PhD. thesis Universidad Politécnica de Madrid, Madrid, Spain.

Chotipanich, S., 2004. Positioning facility management. Facilities, 22(13/14), p. 364-372.

Cotts, D.G. \& Lee, M., 1992. The Facility Management Handbook. New York: AMACOM (American Management Association). 
De Toni, A.F., Fornasier, A., \& Nonino, F., 2006. A taxonomy of the outsourced services industry: towards a definition of Facility Management. Proceedings of the 13th EUROMA Conference (p. 1101-1110).

Duque, L., 2017. Bienestar de los empleados, continuidad de negocio gracias al cambio. Revista Facility Management \& Services, $\mathrm{n}^{\mathrm{o}} 10-2^{\circ}$ Cuatrimestre (p. 52-55).

Ee, S., 2015. Value-based facilities management: how facilities practitioners can deliver competitive advantage to organisation. Singapore: Candid Creation Publishing LLP.

García N., \& Fernández S. J., 2008. Procedimiento de aplicación de trabajo creativo en grupo de expertos. Energética. 2008;29(2):46-50.

García Valdés, M., \& Suárez Marín, M., 2013. El método Delphi para la consulta a expertos en la investigación científica. Revista Cubana de Salud Pública, 39(2), p. 253-267.

Gordon, T. J., 1994. The Delphi method. Futures research methodology, 2(3), 1-30.

Hu, Z. Z., Zhang, J. P., Yu, F. Q., Tian, P. L., \& Xiang, X. S., 2016. Construction and facility management of large MEP projects using a multi-Scale building information model. Advances in Engineering Software, 100, 215-230.

Isa, N. M., Kamaruzzaman, S. N., \& Mohamed, O., 2019. A preliminary survey on facilities management functions in value management process in the construction stage. Journal of Design and Built Environment, 19(2), 30-47.

Ive, A., 2011. Facility management: servizi innovativi e miglioramento continuo. Milano: Guerini e associate.

IFMA, 1992. Competencies for Facility Management Professionals, IFMA, Houston, TX. Cited by Roberts, P. (2001). Corporate competence in FM: current problems and issues. Facilities, 19(7/8), p. 269-275.

Jones, J., \& Hunter, D., 1995. Qualitative research: consensus methods for medical and health services research. BMJ, vol 311, no 7001, p. 376-380.

Kampf, R., 2008. Outsourcing of transport logistic processes, p.198-210. Brno: Tribune EU s.r.o.

Lee, S.Y., 2002. A facility manager's role to provide quality service through reflecting user needs. In: Proceedings of the CIB W070 2002 Global Symposium, Glasgow, 18-20 $0^{\text {th }}$ September 2002. p. 224-231.

Maliene, V., Baldry, D. \& Alexander, K., 2005. FM in the new European dimension. 5th International Postgraduate Research Conference in the Built and Human Environment: 984-992

Myeda, N.E., 2014. Facilities management: the business enabler. Journal of Facilities Management, Vol. 12 No. 4.

Nor, M., \& Azman, N., 2014. Facility management history and evolution. International Journal of Facility Management, 5(1).

Piñeiro, E.M., 2003. La técnica Delphi como estrategia de consulta a los implicados en la evaluación de programas. Revista de investigación educativa, 21(2), p. 449-463.

Price, I., 2002. Can FM evolve? If not, what future?, Journal of Facilities Management, Vol. 1 No. 1, pp. 56-69.

Robles-Garrote, P., \& Rojas, M.C., 2015. La validación por juicio de expertos: dos investigaciones cualitativas en Lingüística aplicada. Revista Nebrija de lingüística aplicada a la enseñanza de lenguas, (18), p. 124-139.

Svensson, K., 1998. Integrating Facilities Management Information, A Process and Product Model Approach. Doctoral Thesis, KTH, Stockholm, Sweden.

Tay, L., \& Ooi, J. T., 2001. Facilities management: a "Jack of all trades”?, Facilities, Vol. 19 No. 10, pp. 357-363.

Then, S.S., 1994. Facilities Management - The relationship between business and property. In Proceedings of the EuroFM/IFMA Conference on Facility Management European Opportunities, Brussels, Belgium (p. 259). 
Then, S.S., 1996. A study of organisational response to the management of operational property assets and facilities support services as a business resource real estate asset management, Unpublished Doctoral Thesis, Heriot-Watt University, Edinburgh, UK.

UNE, 2012. Gestión de Inmuebles y Servicios de Soporte. Parte 1: Términos y definiciones (UNE-EN-152211:2012). Normalización Española (AENOR Internacional), Madrid, 2012.

UNE, 2018. Gestión de bines inmuebles y servicios de soporte - Sistemas de gestión - Requisitos con orientación para su uso. (UNE-ISO 41001:2018). Normalización Española (AENOR Internacional), Madrid, 2018.

Vanegas, B.C., 2011. La investigación cualitativa: un importante abordaje del conocimiento para enfermería. Revista Colombiana de enfermería, 6, 128-142.

Varcoe, B., 2000. Implications for facility management of the changing business climate. Facilities, 18(10/11/12), p. 383-391.

Witkin, B. R. \& Altschuld, J. W., 1995. Planning and conducting needs assessment: A practical guide. Thousand Oaks, Sage 